\title{
Application of ionizing radiation for increasing of microbiological safety and shelf life of cultivated garden berries
}

\author{
Anastasiia Dril* \\ Novosibirsk State Technical University, Prospekt K. Marksa, 20, 630073 Novosibirsk, Russia
}

\begin{abstract}
Healthy nutrition must include fresh fruit and vegetable products containing several nutrients, which are necessary to healthy human body maintaining. Healthy foods, such as fresh cultivated berries, can have dangerous levels of microbiological contamination after their harvesting. There are several methods, including various types of ionizing radiation, which can achieve the safety of plant raw materials safety without damaging their native structure. Thus, environmentally friendly ionizing $\beta$-radiation was used in our experiments. Freshly cultivated garden berries were packed into plastic bags and sealed in a vacuum packaging machine in a passive mode. Then packed samples were processed with ionizing radiation with a dose from 1 to $3 \mathrm{kGy}$. After irradiation, the samples were stored for 21 days at $4{ }^{\circ} \mathrm{C}$. The optimal radiation doses were established for all studied types of cultivated garden berries for increasing their microbiological safety and extend their shelf life. During the experiment, an organoleptic assessment of irradiated berries was carried out in comparison with control samples. It is established that ionizing radiation is an effective way to reduce contamination of berries with pathogenic microorganisms. The research results can be applied for practical purposes to increase the quality and safety of fresh products of plant origin.
\end{abstract}

\section{Introduction}

Food safety and essential food production is of high priority for any country of the world. According to this approach, food production goal is not an uncontrolled growth of the product for satisfying constantly growing needs of people, but rather focusing on ensuring rational and vital human needs. Thereby, the global need for the transition of the world community to sustainable development was proclaimed. The principle of sustainable development assumes that the modern society must satisfy its needs in such a way that next generations will also have enough resources for their life. So, it is necessary to develop technologies and methods of products saving by using environmentally friendly technologies [1].

*Corresponding author: dril@corp.nstu.ru 
In recent years, several difficult epidemiological situations have arisen around the world. In many cases, they are associated with food microbiological contamination with pathogenic microorganisms and the spread of the coronavirus [3]. In an increased risk zone, there are products that have not been subjected to a proper heat treatment, sterilization, cooling, and where the traditional methods of suppressing their microbiological contamination, especially by pathogenic microorganisms, cannot be applied [4]. Fresh fruits, especially seasonal berries, are an example of such foods. The use of fresh berries in a human diet is an important nutrition element, which helps replenishing vitamins and microelements in the organism. Berries also add a variety of taste [5]. In many countries, including Russian Federation, the consumption of seasonal cultivated berries has increased. Berries are supplied to retail business and public catering either from abroad or from local manufacturers in Russia. However, compliance with the safety regulation standards is quite difficult to achieve, due to the large territory of product transporting within the country as well as importing it from other countries. Harvesting berries, their packaging and further transportation, which are affected by customs time delays, increase their microbiological pollution, which has negative influence on the safety level of berries. It is very problematic for many berries to undergo a heat treatment without changing their native structure and keeping their natural vitamin content. The use of ionizing radiation will help reducing the risk of diseases caused by consumption of fresh berries [5, 7]. Among various methods, it can be employed by the effect of accelerated electrons stream. The paper shows the prospects of using $\beta$-radiation for fresh berries treatment. The global experience shows that radiation treatment provides high level of microbiological safety and preserves high quality indicators of fruit and berry products when the optimal irradiation dose is selected.

Besides, one of the priorities in modern science and technology is to prove the practical use of ionizing radiation in the food industry.

To increase the safety level of the studied berry samples and prolong their shelf life, various thermal, chemical, and radiation processing methods are used. The effect of the latter, which include $\alpha-, \beta$-, and $\gamma$-radiation, has not been fully studied. Ionizing radiation method is most effective for fresh berries processing since its external physical effect is negligible [7-9]. When pectin-containing raw materials are exposed to ionizing radiation, their moisture yield increases. This effect is used, for example, in juice production [10]. However, many ionizing radiation factors, which affect plant food raw materials, are still not well studied.

\section{Materials and methods}

In the study, the effect of radiation on organoleptic and microbiological quality indicators of berries was evaluated. Also, the effect of ionizing radiation on the increase of microbiological safety was proved experimentally for the following type of berries: lingonberries (Vaccinium vitis-idaea), blueberries (Vaccinium sp.), black and red currants (Ribes nigrum and Ribes rubrum), and raspberries (Rubus idaeus).

The berry samples were packaged and treated with ionizing radiation directly on the day of the harvest.

Then the samples were irradiated in the Koltsovo Technopark at the EBU-10 (ElectronBeam Unit) radiation processing facility with a directed accelerated electrons stream. With this processing method, radioactive chemical elements and other chemical effects on the product are not used.

The berries were carefully selected and packed in polymer plastic bags in a passive mode, and then sealed. Further the samples were irradiated with an energy of $10 \mathrm{MeV}$ in several doses from 1 to $3 \mathrm{kGy}$ with an interval of $1 \mathrm{kGy}$. Afterwards the samples were stored together with control samples at $4{ }^{\circ} \mathrm{C}$ until one of their quality indicators dropped to 
an unacceptable level (21 days). All studies were carried out when the control and irradiated samples were opened on the sampling day for every seventh day of storage. Then, the samples were examined for organoleptic and microbiological indicators.

\section{Results and discussion}

Organoleptic evaluation of experimental berries samples showed the following results.

Color: there was a general tendency for the color intensity of the samples to decrease in comparison with the control samples when the radiation dose increased from 1 to $3 \mathrm{kGy}$. Native and product characteristics of control samples decreased on the $14^{\text {th }}$ day of storage. The samples slightly changed their color on the $21^{\text {st }}$ day of storage.

Appearance: along with the color change, there was observed moisture separation on the surface of some samples when the radiation dose increased to $3 \mathrm{kGy}$. After 21 days of storage, moisture yield increased noticeably in all samples, and berries size decreased.

Smell: specific berry odor was common to all samples before and after irradiation. During storage, the smell was concentrated in the packages.

Consistency: after irradiation with a dose from 1 to $3 \mathrm{kGy}$, softening of some samples was observed. This effect was observed in the berries treated with a dose of $3 \mathrm{kGy}$, which had the highest degree of maturity. During storage, the moisture yield of the samples increased. On the $21^{\text {st }}$ day of storage, the consistency lost its native state in most of berry samples treated with a dose of $3 \mathrm{kGy}$.

Taste: in the samples, no changes in taste were observed immediately after irradiation. Only during the storage process and microflora growth, their consistency changed, and on the $21^{\text {st }}$ day of storage, foreign taste was registered in all samples.

Due to unique taste and nutritional value, fresh berries are sold at an extremely high price in the international market, and their production grows every year [2,11]. As the number of cultivated berries increases, their spoilage often becomes a serious problem for the industry. Like any fruit, all fresh berries can be processed into berry juice, jam and other products, but their market price is several times higher than that of fresh fruit. Due to rapidly developing irradiation technology, where ionizing radiation is used, the shelf life of fresh berries can be extended to one month $[3-6,12]$.

The results of microbiological indicators of the samples determining during storage are presented in Tables 1-5.

The results from Table 1 show that ionizing radiation has an overwhelming effect on the microflora during the entire storage period, which prevents pathogenic microflora growth. The mold and yeast level detected in untreated control sample exceeded the allowable values after 21 days of storage.

From the indicators presented in Table 2, for blueberry and raspberry samples were found the same tendencies before and after irradiation and during storage. Control samples did not reach the critical values for microbiological safety, since their initial samples were less contaminated in comparison with raspberry samples. Thus, it is possible to extend shelf life of blueberries by another 7 days theoretically.

The indicators from Table 3 show the amount of yeast and mold exceeding in the untreated sample for its $21^{\text {st }}$ day of storage.

According to Table 4, exceeding of the acceptable limits for the detection of molds and yeasts was revealed, while pathogenic microorganisms were not detected.

Table 5 shows that during storage, the microbiological indicators of the samples did not exceed the maximum acceptable values, except for the untreated sample on the $21^{\text {st }}$ day of storage, according to the detected CFU in $1 \mathrm{~g}$ of mold and yeast. 
Table 1. Microbiological indicators of raspberry samples before and after treatment with ionizing radiation, during storage up to 21 days.

\begin{tabular}{|c|c|c|c|c|}
\hline & \multicolumn{4}{|c|}{ Microbiological indicators } \\
\cline { 2 - 5 } $\begin{array}{c}\text { Normative } \\
\text { value }\end{array}$ & $\begin{array}{c}\text { QMAFAnM, } \\
\text { CFU in 1 g }\end{array}$ & $\begin{array}{c}\text { Mold, yeast, } \\
\text { CFU in 1 g }\end{array}$ & $\begin{array}{c}\text { Bacteria of the } \\
\text { group of intestinal } \\
\text { sticks (coliforms) } \\
\text { CFU in 1 g }\end{array}$ & $\begin{array}{c}\text { Pathogenic } \\
\text { microorganisms, } \\
\text { incl. Salmonella, in } \\
\mathbf{2 5 . 0} \text { g }\end{array}$ \\
\hline $\begin{array}{c}\text { Sample codes } \\
\text { dose } / \text { raspberry / } \\
\text { day }\end{array}$ & $2.8 \cdot 10^{4}$ & $5.0 \cdot 10^{2}$ & $\begin{array}{c}\text { not allowed } \\
\text { detected } / \text { not } \\
\text { detected }\end{array}$ & $\begin{array}{c}\text { not allowed } \\
\text { detected } / \text { not detected }\end{array}$ \\
\hline 0 kGy/R/1D & $2.6 \cdot 10^{2}$ & less than 10 & detected & not detected \\
\hline $1 \mathrm{kGy} / \mathrm{R} / 1 \mathrm{D}$ & $2.2 \cdot 10^{2}$ & less than 10 & not detected & not detected \\
\hline $2 \mathrm{kGy} / \mathrm{R} / 1 \mathrm{D}$ & $0.4 \cdot 10^{2}$ & less than 4 & not detected & not detected \\
\hline $3 \mathrm{kGy} / \mathrm{R} / 1 \mathrm{D}$ & none & less than 2 & not detected & not detected \\
\hline $0 \mathrm{kGy} / \mathrm{R} / 7 \mathrm{D}$ & $3.6 \cdot 10^{2}$ & $5.2 \cdot 10$ & detected & not detected \\
\hline $1 \mathrm{kGy} / \mathrm{R} / 7 \mathrm{D}$ & $2.3 \cdot 10^{2}$ & $3.7 \cdot 10$ & not detected & not detected \\
\hline $2 \mathrm{kGy} / \mathrm{R} / 7 \mathrm{D}$ & $4.1 \cdot 10$ & $2.8 \cdot 10$ & not detected & not detected \\
\hline $3 \mathrm{kGy} / \mathrm{R} / 7 \mathrm{D}$ & less than 5 & less than 5 & not detected & not detected \\
\hline $0 \mathrm{kGy} / \mathrm{R} / 14 \mathrm{D}$ & $1.5 \cdot 10^{3}$ & $1.1 \cdot 10^{2}$ & detected & not detected \\
\hline $1 \mathrm{kGy} / \mathrm{R} / 14 \mathrm{D}$ & $1.3 \cdot 10^{3}$ & $7.1 \cdot 10$ & detected & not detected \\
\hline $2 \mathrm{kGy} / \mathrm{R} / 14 \mathrm{D}$ & $8.3 \cdot 10$ & $5.7 \cdot 10$ & detected & not detected \\
\hline $3 \mathrm{kGy} / \mathrm{R} / 14 \mathrm{D}$ & 1 less than 10 & less than 10 & detected & not detected \\
\hline $0 \mathrm{kGy} / \mathrm{R} / 21 \mathrm{D}$ & $4.1 \cdot 10^{4}$ & $5.1 \cdot 10^{2}$ & detected & not detected \\
\hline $1 \mathrm{kGy} / \mathrm{R} / 21 \mathrm{D}$ & $2.1 \cdot 10^{4}$ & $1.4 \cdot 10^{2}$ & detected & not detected \\
\hline $2 \mathrm{kGy} / \mathrm{R} / 21 \mathrm{D}$ & $1.5 \cdot 10^{2}$ & $9.1 \cdot 10$ & detected & not detected \\
\hline $3 \mathrm{kGy} / \mathrm{R} / 21 \mathrm{D}$ & $1.1 \cdot 10^{2}$ & $2.1 \cdot 10$ & detected & not detected \\
\hline
\end{tabular}

Table 2. Microbiological indicators of blueberry samples before and after treatment with ionizing radiation, during storage up to 21 days.

\begin{tabular}{|c|c|c|c|c|}
\hline & \multicolumn{4}{|c|}{ Microbiological indicators } \\
\cline { 2 - 5 } Normative value & $\begin{array}{c}\text { QMAFAnM, } \\
\text { CFU in 1 g }\end{array}$ & $\begin{array}{c}\text { Mold, yeast, } \\
\text { CFU in 1 g }\end{array}$ & $\begin{array}{c}\text { Bacteria of the } \\
\text { group of intestinal } \\
\text { sticks (coliforms) } \\
\text { CFU in 1 g }\end{array}$ & $\begin{array}{c}\text { Pathogenic } \\
\text { microorganisms, } \\
\text { incl. Salmonella, in } \\
\mathbf{2 5 . 0} \text { g }\end{array}$ \\
\hline $\begin{array}{c}\text { Sample codes } \\
\text { dose } / \text { raspberry } / \\
\text { day }\end{array}$ & $2.8 \cdot 10^{4}$ & $5.0 \cdot 10^{2}$ & $\begin{array}{c}\text { not allowed } \\
\text { detected } / \text { not } \\
\text { detected }\end{array}$ & $\begin{array}{c}\text { not allowed } \\
\text { detected } / \text { not detected }\end{array}$ \\
\hline $0 \mathrm{kGy} / \mathrm{B} / 1 \mathrm{D}$ & $3.1 \cdot 10^{2}$ & less than 5 & detected & not detected \\
\hline $1 \mathrm{kGy} / \mathrm{B} / 1 \mathrm{D}$ & $1.1 \cdot 10^{2}$ & less than 5 & not detected & not detected \\
\hline $2 \mathrm{kGy} / \mathrm{B} / 1 \mathrm{D}$ & $6.5 \cdot 10$ & none & not detected & not detected \\
\hline $3 \mathrm{kGy} / \mathrm{B} / 1 \mathrm{D}$ & none & none & not detected & not detected \\
\hline $0 \mathrm{kGy} / \mathrm{B} / 7 \mathrm{D}$ & $5.7 \cdot 10^{2}$ & $2.1 \cdot 10$ & detected & not detected \\
\hline $1 \mathrm{kGy} / \mathrm{B} / 7 \mathrm{D}$ & $6.3 \cdot 10^{2}$ & $1.9 \cdot 10$ & not detected & not detected \\
\hline $2 \mathrm{kGy} / \mathrm{B} / 7 \mathrm{D}$ & $4.2 \cdot 10$ & $1.0 \cdot 10$ & not detected & not detected \\
\hline $3 \mathrm{kGy} / \mathrm{B} / 7 \mathrm{D}$ & 1 ess than 10 & less than 10 & not detected & not detected \\
\hline $0 \mathrm{kGy} / \mathrm{B} / 14 \mathrm{D}$ & $9.6 \cdot 10^{2}$ & $1.3 \cdot 10^{2}$ & not detected & not detected \\
\hline $1 \mathrm{kGy} / \mathrm{B} / 14 \mathrm{D}$ & $9.3 \cdot 10^{2}$ & $7.4 \cdot 10$ & not detected & not detected \\
\hline $2 \mathrm{kGy} / \mathrm{B} / 14 \mathrm{D}$ & $6.5 \cdot 10$ & $3.9 \cdot 10$ & not detected & not detected \\
\hline $3 \mathrm{kGy} / \mathrm{B} / 14 \mathrm{D}$ & 1 less than 10 & less than 10 & not detected & not detected \\
\hline $0 \mathrm{kGy} / \mathrm{B} / 21 \mathrm{D}$ & $6.1 \cdot 10^{3}$ & $2.6 \cdot 10^{2}$ & detected & not detected \\
\hline $1 \mathrm{kGy} / \mathrm{B} / 21 \mathrm{D}$ & $4.1 \cdot 10^{3}$ & $2.9 \cdot 10^{2}$ & detected & not detected \\
\hline $2 \mathrm{kGy} / \mathrm{B} / 21 \mathrm{D}$ & $8.5 \cdot 10^{2}$ & $9.8 \cdot 10$ & detected & not detected \\
\hline $3 \mathrm{kGy} / \mathrm{B} / 21 \mathrm{D}$ & $9.1 \cdot 10$ & $8.1 \cdot 10$ & detected & not detected \\
\hline
\end{tabular}


Table 3. Microbiological indicators of lingonberry samples before and after treatment with ionizing radiation, during storage up to 21 days.

\begin{tabular}{|c|c|c|c|c|}
\hline \multirow[b]{2}{*}{ Normative value } & \multicolumn{4}{|c|}{ Microbiological indicators } \\
\hline & $\begin{array}{l}\text { QMAFAnM, } \\
\text { CFU in } 1 \mathrm{~g}\end{array}$ & $\begin{array}{l}\text { Mold, yeast, } \\
\text { CFU in } 1 \mathrm{~g}\end{array}$ & $\begin{array}{l}\text { Bacteria of the } \\
\text { group of intestinal } \\
\text { sticks (coliforms) } \\
\text { CFU in } 1 \mathrm{~g}\end{array}$ & $\begin{array}{c}\text { Pathogenic } \\
\text { microorganisms, } \\
\text { incl. Salmonella, in } \\
\mathbf{2 5 . 0 \mathrm { g }}\end{array}$ \\
\hline $\begin{array}{c}\text { Sample codes } \\
\text { dose / raspberry / } \\
\text { day }\end{array}$ & $2.8 \cdot 10^{4}$ & $5.0 \cdot 10^{2}$ & $\begin{array}{c}\text { not allowed } \\
\text { detected /not } \\
\text { detected }\end{array}$ & $\begin{array}{c}\text { not allowed } \\
\text { detected / not detected }\end{array}$ \\
\hline $0 \mathrm{kGy} / \mathrm{L} / 1 \mathrm{D}$ & $3.8 \cdot 10^{2}$ & less than 10 & detected & not detected \\
\hline $1 \mathrm{kGy} / \mathrm{L} / 1 \mathrm{D}$ & $2.2 \cdot 10^{2}$ & less than 10 & not detected & not detected \\
\hline $2 \mathrm{kGy} / \mathrm{L} / 1 \mathrm{D}$ & $1.5 \cdot 10^{2}$ & less than 5 & not detected & not detected \\
\hline $3 \mathrm{kGy} / \mathrm{L} / 1 \mathrm{D}$ & none & less than 5 & not detected & not detected \\
\hline $0 \mathrm{kGy} / \mathrm{L} / 7 \mathrm{D}$ & $9.8 \cdot 10^{2}$ & $5.1 \cdot 10$ & not detected & not detected \\
\hline $1 \mathrm{kGy} / \mathrm{L} / 7 \mathrm{D}$ & $6.4 \cdot 10^{2}$ & $3.6 \cdot 10$ & not detected & not detected \\
\hline $2 \mathrm{kGy} / \mathrm{L} / 7 \mathrm{D}$ & $7.2 \cdot 10$ & $2.8 \cdot 10$ & not detected & not detected \\
\hline $3 \mathrm{kGy} / \mathrm{L} / 7 \mathrm{D}$ & less than 5 & less than 5 & not detected & not detected \\
\hline $0 \mathrm{kGy} / \mathrm{L} / 14 \mathrm{D}$ & $1.6 \cdot 10^{3}$ & $1.4 \cdot 10^{2}$ & detected & not detected \\
\hline $1 \mathrm{kGy} / \mathrm{L} / 14 \mathrm{D}$ & $1.3 \cdot 10^{3}$ & $6.8 \cdot 10$ & not detected & not detected \\
\hline $2 \mathrm{kGy} / \mathrm{L} / 14 \mathrm{D}$ & $8.3 \cdot 10$ & $7.9 \cdot 10$ & not detected & not detected \\
\hline $3 \mathrm{kGy} / \mathrm{L} / 14 \mathrm{D}$ & less than 10 & less than 10 & not detected & not detected \\
\hline $0 \mathrm{kGy} / \mathrm{L} / 21 \mathrm{D}$ & $4.1 \cdot 10^{4}$ & $5.3 \cdot 10^{2}$ & less than 5 & not detected \\
\hline $1 \mathrm{kGy} / \mathrm{L} / 21 \mathrm{D}$ & $2.1 \cdot 10^{4}$ & $1.8 \cdot 10^{2}$ & detected & not detected \\
\hline $2 \mathrm{kGy} / \mathrm{L} / 21 \mathrm{D}$ & $1.5 \cdot 10^{4}$ & $2.8 \cdot 10^{2}$ & detected & not detected \\
\hline $3 \mathrm{kGy} / \mathrm{L} / 21 \mathrm{D}$ & $5.2 \cdot 10$ & $9.2 \cdot 10$ & detected & not detected \\
\hline
\end{tabular}

Table 4. Microbiological indicators of red currant samples before and after treatment with ionizing radiation, during storage up to 21 days.

\begin{tabular}{|c|c|c|c|c|}
\hline \multirow[b]{2}{*}{ Normative value } & \multicolumn{4}{|c|}{ Microbiological indicators } \\
\hline & $\begin{array}{l}\text { QMAFAnM, } \\
\text { CFU in } 1 \mathrm{~g}\end{array}$ & $\begin{array}{l}\text { Mold, yeast, } \\
\text { CFU in } 1 \mathrm{~g}\end{array}$ & $\begin{array}{l}\text { Bacteria of the } \\
\text { group of intestinal } \\
\text { sticks (coliforms) } \\
\text { CFU in } 1 \mathrm{~g}\end{array}$ & $\begin{array}{c}\text { Pathogenic } \\
\text { microorganisms, } \\
\text { incl. Salmonella, in } \\
25.0 \mathrm{~g}\end{array}$ \\
\hline $\begin{array}{c}\text { Sample codes } \\
\text { dose / raspberry / } \\
\text { day }\end{array}$ & $2.8 \cdot 10^{4}$ & $5.0 \cdot 10^{2}$ & $\begin{array}{c}\text { not allowed } \\
\text { detected } / \text { not } \\
\text { detected }\end{array}$ & $\begin{array}{c}\text { not allowed } \\
\text { detected /not detected }\end{array}$ \\
\hline $0 \mathrm{\kappa Gy} / \mathrm{RC} / 1 \mathrm{D}$ & $1.8 \cdot 10^{2}$ & less than 10 & detected & not detected \\
\hline $1 \mathrm{\kappa Gy} / \mathrm{RC} / 1 \mathrm{D}$ & $1.1 \cdot 10^{2}$ & less than 10 & not detected & not detected \\
\hline 2 кGy/RC/1D & $0.5 \cdot 10^{2}$ & less than 5 & not detected & not detected \\
\hline 3 кGy/RC/1D & less than 5 & less than 5 & not detected & not detected \\
\hline 0 кGy/RC/7D & $6.8 \cdot 10^{2}$ & $5.1 \cdot 10$ & detected & not detected \\
\hline 1 кGy/RC/7D & $2.2 \cdot 10^{2}$ & $3.6 \cdot 10$ & not detected & not detected \\
\hline 2 кGy/RC/7D & $1.2 \cdot 10$ & $2.8 \cdot 10$ & not detected & not detected \\
\hline 3 кGy/RC/7D & less than 10 & $1.3 \cdot 10$ & not detected & not detected \\
\hline 0 кGy/RC/14D & $1.6 \cdot 10^{3}$ & $1.2 \cdot 10^{2}$ & detected & not detected \\
\hline 1 кGy/RC/14D & $1.3 \cdot 10^{3}$ & $7.4 \cdot 10$ & detected & not detected \\
\hline 2 KGy/RC/14D & $2.3 \cdot 10^{2}$ & $5.9 \cdot 10$ & detected & not detected \\
\hline 3 кGy/RC/14D & $1.8 \cdot 10^{2}$ & $3.8 \cdot 10$ & detected & not detected \\
\hline 0 кGy/RC/21D & $2.1 \cdot 10^{4}$ & $5.6 \cdot 10^{2}$ & detected & not detected \\
\hline $1 \mathrm{\kappa Gy} / \mathrm{RC} / 21 \mathrm{D}$ & $8.1 \cdot 10^{2}$ & $1.8 \cdot 10^{2}$ & detected & not detected \\
\hline 2 кGy/RC/21D & $1.1 \cdot 10^{2}$ & $8.8 \cdot 10$ & detected & not detected \\
\hline $3 \mathrm{\kappa Gy} / \mathrm{RC} / 21 \mathrm{D}$ & $1.8 \cdot 10$ & $6.8 \cdot 10$ & detected & not detected \\
\hline
\end{tabular}


Table 5. Microbiological indicators of black currant samples before and after treatment with ionizing radiation, during storage up to 21 days.

\begin{tabular}{|c|c|c|c|c|}
\hline \multirow[b]{2}{*}{ Normative value } & \multicolumn{4}{|c|}{ Microbiological indicators } \\
\hline & $\begin{array}{l}\text { QMAFAnM, } \\
\text { CFU in } 1 \mathrm{~g}\end{array}$ & $\begin{array}{l}\text { Mold, yeast, } \\
\text { CFU in } 1 \mathrm{~g}\end{array}$ & $\begin{array}{l}\text { Bacteria of the } \\
\text { group of intestinal } \\
\text { sticks (coliforms) } \\
\text { CFU in } 1 \mathrm{~g}\end{array}$ & $\begin{array}{c}\text { Pathogenic } \\
\text { microorganisms, } \\
\text { incl. Salmonella, in } \\
\mathbf{2 5 . 0 \mathrm { g }}\end{array}$ \\
\hline $\begin{array}{c}\text { Sample codes } \\
\text { dose / raspberry / } \\
\text { day }\end{array}$ & $2.8 \cdot 10^{4}$ & $5.0 \cdot 10^{2}$ & $\begin{array}{c}\text { not allowed } \\
\text { detected } / \text { not } \\
\text { detected }\end{array}$ & $\begin{array}{c}\text { not allowed } \\
\text { detected / not detected }\end{array}$ \\
\hline $0 \mathrm{kGy} / \mathrm{BC} / 1 \mathrm{D}$ & $5.8 \cdot 10^{2}$ & less than 10 & detected & not detected \\
\hline $1 \mathrm{kGy} / \mathrm{BC} / 1 \mathrm{D}$ & $3.2 \cdot 10^{2}$ & less than 10 & not detected & not detected \\
\hline $2 \mathrm{kGy} / \mathrm{BC} / 1 \mathrm{D}$ & $1.5 \cdot 10^{2}$ & less than 5 & not detected & not detected \\
\hline $3 \mathrm{kGy} / \mathrm{BC} / 1 \mathrm{D}$ & less than 5 & less than 5 & not detected & not detected \\
\hline $0 \mathrm{kGy} / \mathrm{BC} / 7 \mathrm{D}$ & $9.8 \cdot 10^{2}$ & $2.1 \cdot 10$ & detected & not detected \\
\hline $1 \mathrm{kGy} / \mathrm{BC} / 7 \mathrm{D}$ & $9.4 \cdot 10^{2}$ & $1.8 \cdot 10$ & not detected & not detected \\
\hline $2 \mathrm{kGy} / \mathrm{BC} / 7 \mathrm{D}$ & $3.8 \cdot 10^{2}$ & $1.5 \cdot 10$ & not detected & not detected \\
\hline $3 \mathrm{kGy} / \mathrm{BC} / 7 \mathrm{D}$ & less than 10 & less than 10 & not detected & not detected \\
\hline $0 \mathrm{kGy} / \mathrm{BC} / 14 \mathrm{D}$ & $1.2 \cdot 10^{3}$ & $1.3 \cdot 10^{2}$ & detected & not detected \\
\hline $1 \mathrm{kGy} / \mathrm{BC} / 14 \mathrm{D}$ & $2.3 \cdot 10^{3}$ & $5.4 \cdot 10$ & detected & not detected \\
\hline $2 \mathrm{kGy} / \mathrm{BC} / 14 \mathrm{D}$ & $8.3 \cdot 10^{2}$ & $3.9 \cdot 10$ & detected & not detected \\
\hline $3 \mathrm{kGy} / \mathrm{BC} / 14 \mathrm{D}$ & $1.7 \cdot 10$ & $2.3 \cdot 10$ & detected & not detected \\
\hline $0 \mathrm{kGy} / \mathrm{BC} / 21 \mathrm{D}$ & $1.1 \cdot 10^{4}$ & $5.6 \cdot 10^{2}$ & detected & not detected \\
\hline $1 \mathrm{kGy} / \mathrm{BC} / 21 \mathrm{D}$ & $2.1 \cdot 10^{4}$ & $1.8 \cdot 10^{2}$ & detected & not detected \\
\hline $2 \mathrm{kGy} / \mathrm{BC} / 21 \mathrm{D}$ & $2.2 \cdot 10^{3}$ & $9.8 \cdot 10$ & detected & not detected \\
\hline $3 \mathrm{kGy} / \mathrm{BC} / 21 \mathrm{D}$ & $9.3 \cdot 10$ & $9.3 \cdot 10$ & detected & not detected \\
\hline
\end{tabular}

For all microbiological indicators, on the $21^{\text {st }}$ day of storage the upper limit value of mold and yeast content was exceeded by the CFU in $1 \mathrm{~g}$ in untreated samples. The growth of this type of microorganisms was facilitated by initial parameters of the samples and the ability of several moldy fungi and yeast to multiply in a sealed package at a low oxygen content [6-7]. Based on recent research, the combination of controlled atmosphere with irradiation can help suppressing microorganisms' growth and reproduction [7].

\section{Conclusions}

Ensuring microbiological safety using an environmentally friendly method of suppressing the growth of microorganisms in food products is a priority area in many developed countries, which have national programs of resource and energy conservation development $[1,11,12]$. With the steady growth of cities and their populations, there is a need in supporting consumers with fresh and safe food products and reducing the risk of using contaminated plant products. The result of carried out study shows how to disinfect and reduce microflora in fresh berries, while their shelf life is increased. The positive effect of ionizing radiation on the microbiological safety of samples has been pointed out as well. It has been demonstrated that irradiation is an effective method for reducing of several microorganisms immediately after irradiation and slowing down their further growth during storage. The effect on the pulp structure of the experimental samples with a dose of radiation from 1 to $3 \mathrm{kGy}$ in comparison with control samples was established. There is also a tendency for color and consistency changing of berry samples during storage. So organoleptic parameters decrease at irradiation dose of $3 \mathrm{kGy}$. Therefore, recommended irradiation dose for studied berries is a dose of up to $2 \mathrm{kGy}$ inclusive. At this level, the preservation of organoleptic properties and the acceptable level of microbiological indicators are guaranteed. 
Many types of fruit and vegetable products consumed by urban population cannot have full guarantee concerning their microbiological safety, since is not possible to control every point of their way from manufacturers to consumers. Some of imported fruits, vegetables and berries are irradiated after harvest or at the border of the exporting country. Summarizing the scientific data on the impact of ionizing radiation on plant raw materials, it is possible to create a working tool for its practical application and the development of specialized methods and standards in Russian Federation. This will allow food resources preservation, thereby providing the way to sustainable development. A few developed countries such as the USA, Australia as well as the European Union countries have already taken these opportunities [8].

\section{References}

1. N. A. Kazhuro, Science \& Technique, 6, 511 (2016)

2. J. Song, X. Meng, T. Yan, B. Li, H. Shang, Food Science, 36 (2015)

3. A. I. Pimenta, F. Margaça, S. Cabo Verde, Int. J. Food Microbiol, 2, 89 (2019)

4. K. M. Phillips, M. Council-Trouche, R. C. McGinty, A. S. Rasor, M. T. Tarrago-Trani. J. Food Compos. Anal., 45, 147 (2016)

5. S. Skrovankova, D. Sumczynski, J. Mlcek, T. Jurikova, J. Sochor, Int. J. Mol. Sci., 16, 24673 (2015)

6. D. Guerreiro, J. Madureira, T. Silva, R. Melo, P. M. P. Santos, A. Ferreira, M. J. Trigo, A. N. Falcão, F. M. A. Margaça, S. Cabo Verde, Innov. Food Sci. Emerg. Technol., 36, 1 (2016)

7. M. T. Munir, M. Federighi, Foods, 9, 878 (2020)

8. G. J. Hallman Food Control, B, 372 (2017)

9. A. Prakash, Radiat. Phys. Chem., 129, 50 (2016)

10. A. N. Petrov, N. S Shishkina., N. I. Shatalova, Prospects for the use of ionizing radiation to optimize the technology of storage and processing of fruits and vegetables, 222 (2018)

11. I. Ihsanullah, A. Rashid, Food Control, B, 345 (2017)

12. J. Zhao, J. Ma, M. Wu, X. Jiao, G. Zhan, Food Control, B, 360 (2017) 